Sultan Qaboos University Journal of Arts \& Social Sciences
جامعة السلطان قابوس

مجلة الآداب والعلوم الاجتمأعية

\title{
Changes in Prospective Teachers' Beliefs about Foreign Language Learning in a Teacher Training Program
}

\begin{tabular}{c}
\hline Adel Abu Radwan \\
\hline Associate Professor \\
Department of English Language and \\
Literature \\
Sultan Qaboos University \\
radwan@squ.edu.om
\end{tabular}




\title{
Changes in Prospective Teachers' Beliefs about Foreign Language Learning in a Teacher Training Program
}

\author{
Adel Abu Radwan
}

Abstract:

This study examines changes in the beliefs of a group of undergraduate students about learning and teaching English as a foreign language. Learners' beliefs are thought to shape students' language learning experience and often guide their future teaching practices. Thus, any mistaken beliefs could negatively affect student learning and teaching experience for decades (Peacock, 2001). While some studies suggest that students' beliefs are stable, inflexible and resistant to change, others show that students' beliefs are amenable to change with proper intervention. This study uses a questionnaire to collect data from 212 students in the English Department at Sultan Qaboos University. The results show that learners hold strong beliefs about the role of vocabulary, grammar and practice in learning a foreign language. Moreover, their beliefs did not undergo any significant changes during the duration of the program though slight shifts in their beliefs could be noticed in the final year of their training. The study suggests that special attention should be given to this area to eliminate any detrimental beliefs held by prospective teachers. Early intervention may steer students in the right direction and could equip them with the theoretical and pedagogical beliefs necessary to positively influence their future students.

Keywords: Learners' Beliefs; English as a Foreign Language; Detrimental Beliefs.

\section{التغييرات في معتقدات الطلاب حول تعلم اللغة الأجنبية في برنامج تدريب معلمي اللغة الإنجليزية في جامعة السلطان قابوس تعاب الاجس}

عادل أبو رضوان

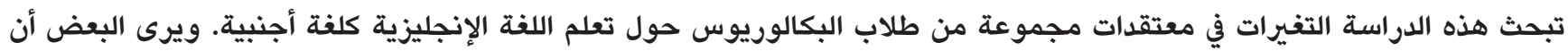

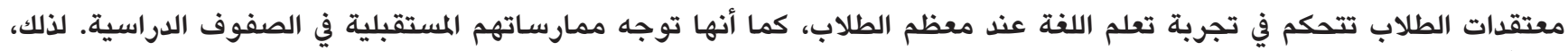

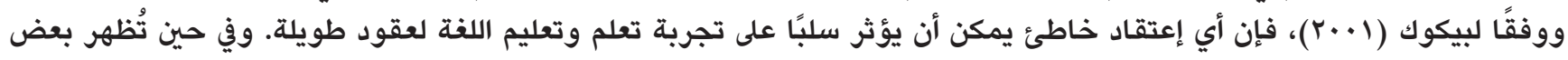

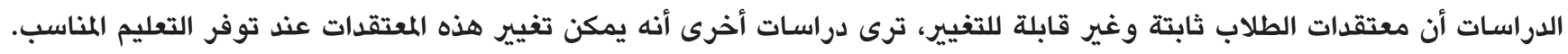

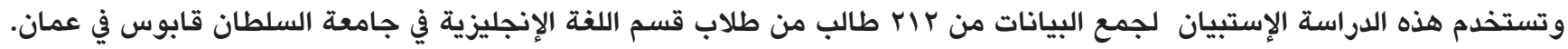

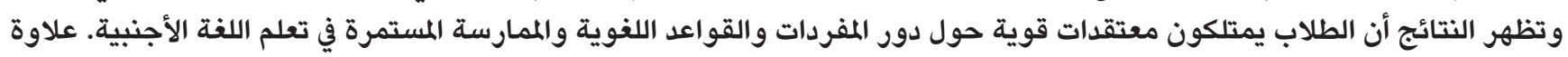

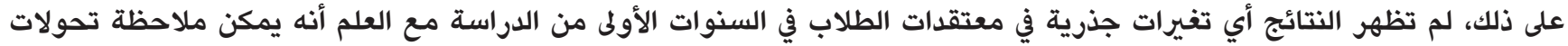

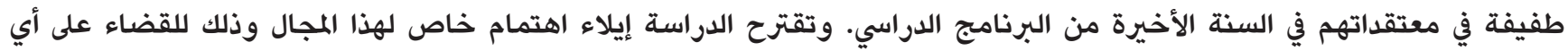

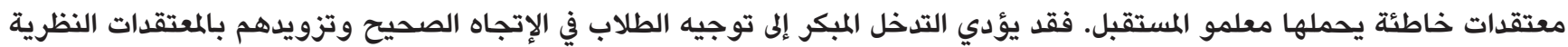
والتربوية الضرورية للتأثير على طلابهم المستقبليين بشكل إيجابي. 


\section{Introduction}

Foreign language learning research has extensively explored learners' beliefs about foreign/second language learning (see e.g., Debreli, 2012; Graber, 1996; Fang, 1996; Horwitz, 1985, 1988; Nettle, 1998; Peacock, 2001, among others). This research has shown that teachers starting their professional career often carry with them, as a result of previous learning experiences, a definite set of deeply held beliefs and assumptions about language learning and teaching (Mattheoudakis, 2006). These beliefs, according to Richards and Rodgers (2001), tend to shape their approaches to language teaching and inform and guide their teaching practices. Hence, "understanding the belief structures of teachers and teacher candidates is essential to improving their professional preparation and teaching practices" (Pajares, 1992, p. 307).

Work in this area was originally pioneered by Horwitz $(1985,1987)$ who showed that some commonly held learners' beliefs could be detrimental to their progress in learning a second language. Horwitz (1988) and others (see, e.g., Kern, 1995; Samimy \& Lee, 1997) suggest, for example, that learners who believe in the importance of grammar are likely to spend considerable time focusing almost exclusively on memorizing grammar rules and paying less attention to other tasks. As these learners become teachers, they are likely to steer their future students into the same type of activities they were engaged in during their training. It is, therefore, critical to help these prospective teachers eliminate any detrimental beliefs before they start their careers as EFL teachers. Research in this area has investigated amenability of students' beliefs to change. Several studies (see, e.g., Johnson, 1994; Peacock, 2001; Powell, 1992; Tatto, 1998; Wenden, 1987) suggest that students' beliefs about learning and teaching are deeply entrenched and resistant to change. Conversely, many other researchers (see, e.g., Mattheoudakis, 2007; Nettle, 1998; Sendan 1995) question this premise and report changes in learners' beliefs during their training program and also after joining the teaching profession. These studies argue that changes in learners' beliefs are usually gradual, cumulative, and vary by individuals and the nature of the belief. These contradictory findings and the relative paucity of such research within non-native and non-western contexts, particularly among prospective EFL teachers, call for further research into this essential EFL area in order to have a clear understanding of the nature of the beliefs which these learners have and their possible impact on their future teaching practices. In addition, little research has examined the relationship between learners' deeply held beliefs and their success in learning a foreign language. This study, thus, seeks to explore both issues.

\section{Literature Review}

Horwitz's (1985) seminal work investigated the beliefs which EFL trainee teachers hold about language learning and teaching. Her self-report questionnaire BALLI (Beliefs About Language Learning Inventory) and several slightly modified versions of it have been used in numerous studies (see, e.g., Debreli, 2012; Kern, 1995; Peacock, 1999, 2001; Samimy \& Lee, 1997; Tatto, 1998) to raise awareness about the nature of learners' beliefs and their possible impact on teachers and students alike. These studies and many others have generally shown that students and prospective teachers often hold many incorrect beliefs about learning and teaching foreign languages and that these beliefs shape to a large extent their teaching strategies and methodologies, the tasks and materials they use in classrooms, their testing practices as well as other classroom activities and practices (see, e.g., Clark \& Peterson, 1986; Erkmen, 2010). Therefore, changing learners' beliefs in a positive way can have a profound effect on their learning and future practices (Dweck, 2006).

Richards and Lockhart (1996, p. 36) state that "teaching is a very personal activity, and it is not surprising that individual teachers bring to teaching very different beliefs and assumptions about what constitutes effective teaching." In this regard, any incorrect beliefs about foreign language learning and teaching can be detrimental to the students' own learning and might negatively affect their future practices. For instance, teachers who believe in the communicative nature of language learning are likely to adopt methodologies, techniques, activities and materials which are conducive to that view of learning and teaching. Conversely, a more traditional view which emphasizes teaching grammar is likely to steer the classroom's direction into more grammar-oriented teaching practices. In addition, as shown by Horwitz (1988), Peacock (1999, 2001) and Samimy and Lee (1997), learners who believe in the importance of grammar and learning and memorizing rules will be dissatisfied with language classes that ignore these aspects of language learning and focus more on communicative activities. Similarly, those learners who think that learning a new language involves learning a lot of new lexical items are likely to be unhappy with instruction that does not integrate this component in everyday classroom activities. This is exactly what Puchta (1999, cited in Peacock, 2001, p. 181) emphasizes when he mentions that "beliefs are guiding principles for our students' behavior and strong perceptual filters." He 
adds that beliefs shape how teachers interpret new information and experiences.

Pajares (1992) and many other researchers (see, e.g., Borg, 2006; Peacock, 2001; Nettle, 1998; Wenden, 1987) contend that pre-service teachers' earlyestablished beliefs are resistant to change even if they are proved to be inappropriate. For instance, Wenden (1987) showed that student trainees strongly hold to beliefs acquired within a specific educational system regardless of efforts to change them. Similarly, Peacock's (2001) longitudinal study of students' beliefs corroborated this conclusion, showing that their beliefs remained almost stable throughout the duration of the students' program of study. Likewise, Borg (2006) concludes that learners' beliefs usually persist with them and may become less amenable to change, and they often guide how they perceive and interpret new information presented to them. Hence, as asserted by Richardson (2003), learners' and teachers' beliefs can be a "stumbling block" to new instructional changes, since they are difficult to alter. This position is in stark contrast with the findings of other researchers (see, e.g., Joram and Gabriele, 1998; Nettle, 1998; Mattheoudakis, 2007, among others). Joram and Gabriele (1998) showed that incorrect beliefs about learning a language can be effectively targeted during teacher training. Brown and McGannon (1998) also concur with this position and provide empirical evidence that some, though not all, common beliefs about language learning including the role of intelligence, error correction, first language interference, etc. can be positively altered following a short teaching practicum which introduces the trainees to a different set of beliefs about language learning and teaching. In addition, Nettle $(1996,1998)$ suggests that focused practice teaching targeting teachers' prior beliefs has significantly impacted these beliefs. Similarly, Mattheoudakis (2007) asserted that appropriate intervention can have a positive impact and may lead to elimination of any detrimental trainee beliefs. He showed that pre-service teachers' beliefs changed considerably when these trainees underwent a program of study in SLA and methodology. Likewise, MacDonald, Badger and White (2001) showed that student teachers' beliefs about traditional behavioristic views regarding language learning changed significantly after undertaking a relatively short course of study on theories of second language learning.

These two diametrically contradictory positions suggest a need for further research into this issue, especially in contexts where the issue has relatively been rarely addressed. Most of the research conducted in this area has been carried out in ESL contexts with native teachers in various teaching programs (Debreli, 2012). EFL contexts, such as Oman's, point to a noticeable shortage of such research despite the importance of this area. To my knowledge, El-Okda (2005) is the only study to explore this issue within the Omani context. This study showed that students' earlyestablished beliefs shape their practices in teaching methods courses. The relative scarcity of research in this area has also been emphasized by Peacock (2001) who contends that despite the importance of teachers and students' beliefs, this area is still underresearched. Hence, this study is an attempt to fill this gap by exploring the beliefs of pre-service students in a non-native and non-western context and examining whether these beliefs change over the length of a long training program and how they might influence students' proficiency in the target language.

\section{The Study}

The present study seeks to examine the impact of the EFL teachers' training program at Sultan Qaboos University (SQU) in Oman on students' beliefs about language teaching and learning. It will examine the commonly held beliefs of these students and the correlation between these beliefs and several variables, including length of study in the program, teaching experience, and learners' proficiency in the foreign language. Specifically, the study attempts to answer the following research questions:

1. What beliefs do students in the EFL teacher training program at SQU hold about English language teaching and learning?

2. Do students' beliefs about English language teaching and learning change over the duration of their study in the English teacher training program?

3. Do students with teaching experience differ from students with no teaching experience in their beliefs about English language teaching and learning?

4. Are there any differences among students in their beliefs about English language teaching and learning due to proficiency differences as measured by their GPAs? (i.e. is there any correlation between students' beliefs and their English proficiency?)

5. What beliefs about English language teaching and learning are predictive of success in learning a foreign language?

\subsection{Participants}

A total of 212 students majoring in English participated in this study, but only 197 returned their questionnaires completely answered. Due to the demography of the English program at SQU where the ratio of male to female students approaches 1 to 4 , the 
number of female students far exceeded the number of male participants (167 females, and 30 males). These participants were freshmen (32), sophomores (39), juniors (75) and seniors (51). As for proficiency in English, unfortunately, due to financial and logistical considerations, it was not possible to administer any standardized test to the participants in this study. Therefore, their GPAs in English courses were used as an indicator of their proficiency in English. Accordingly, the participants were divided into two groups: B-and-above (112 participants) and C-andbelow (85 participants). A total of 89 participants indicated they had experience in teaching English as a foreign language while 108 had no teaching experience. The following table presents a summary of the participants' demographic information.

\subsection{Instrument}

Research in this area has utilized a range of methodologies, including questionnaires (Horwitz, 1985; Peacock, 2001), think-aloud protocols (Barcelos, 2003), observations (Feryok, 2008), openended questions (Bartels, 2005), and close-ended questionnaires (Agathopoulou, 2010). This study used the learner self-report questionnaire (BALLI) modified from Horwitz (1985) to collect data about students' beliefs. The questionnaire, having a high level of reliability, has been used widely in numerous studies to explore students' beliefs about language learning and teaching. This study's questionnaire, which consisted of 36 statements reflecting different learners' beliefs, used a five-point Likert-type scale ranging from 1 ("Strongly Disagree") to 5 ("Strongly Agree"). The first part of the questionnaire collected biographical information about the participants such as gender, year of study, self-perceived proficiency, GPA in English courses, and experience in teaching English as a foreign language.

\subsection{Data Collection Procedure}

To ensure participation of students from different years of study (freshmen, sophomores, juniors, and seniors), the questionnaire was distributed to regular classes with the help of the classes' instructors who were informed of the nature of the task ahead of time. The students took an average of 27 minutes to finish the questionnaire. Of the 212 distributed questionnaires, only 197 were fully completed. The 15 incomplete questionnaires were discarded. Data analysis was conducted using the SPSS statistical program to obtain descriptive and inferential statistics.

\section{Results and Analysis}

The first research question seeks to identify the most commonly held beliefs students have about language learning and teaching. A frequency analysis of students' data shows that they strongly believe in the role of vocabulary and grammar, which are considered by Horwitz (1985) the most critical language learning beliefs. Overall, the results show that the majority of students emphasize the importance of vocabulary in learning a new language. Approximately $98.5 \%$ of the participants either agree or strongly agree with the statement about the value of vocabulary, thus making it the strongest belief they have about learning a new language.

The second highest belief has to do with the role of grammar. Separated only by a fraction of a percentage from the first belief, $98 \%$ of the participants believe that learning grammar is critical to language learning. These results concur with Peacock (2001) and Horwitz (1985) who rank these two beliefs along with intelligence among the top beliefs held by learners; however, a noticeable difference between the present study and these two studies is that students in this study do not accord the same level of significance to the role of intelligence in learning a new language. Only $70 \%$ of the participants agree that people who speak more than one language are intelligent. Contrary to these two studies, the third place in this study is occupied by a statement about the importance of practicing language, which is also asserted in the fifth-ranked statement, which focuses on the importance of having opportunities to use the language in language learning.

The fourth most important belief relates to the job prospects which English avails to learners. As teacher trainees, higher levels of proficiency in the language almost guarantees most graduates of the program a job with the government as English language instructors. One of the lowest-ranked beliefs is the belief that Arabic and English are structurally similar. This is unsurprising as the two languages belong to two different language families and are syntactically and morphologically different. The lowest-ranked belief is the one which assumes that English is a difficult language to learn. Despite their variable levels of success in acquiring English and having different proficiency levels, the participants almost unanimously believe that English is not difficult to learn.

The cultural impact is reflected in the results. While in Peacock's study of Chinese learners $84 \%$ of the respondents agree that "You should not say anything in the foreign language until you can speak it correctly", only $12 \%$ of the respondents in this study agree with this statement. This is probably due to the nature of the Arabic culture which, as pointed out by Koch 
(1983), is more oral in its styles than the Chinese. The learners, in this regard, are a product of their culture. An interesting finding is that while around $91 \%$ of the participants believe in the role of aptitude in acquiring English as shown in the statement "Some people are born with a special ability which helps them learn a foreign language", only $46 \%$ believe they have the

Table 1: Demographic description of the participants

\begin{tabular}{|c|c|c|c|}
\hline \multirow{2}{*}{ Study Level } & & N & $\%$ \\
\cline { 2 - 4 } & Freshman & 32 & $16 \%$ \\
\hline & Sophomore & 39 & $20 \%$ \\
\hline \multirow{2}{*}{ GPA } & Junior & 75 & $38 \%$ \\
\hline \multirow{2}{*}{ Teaching } & Senior & 51 & $26 \%$ \\
\hline & B-and-above & 112 & $57 \%$ \\
\hline & C-and-below & 85 & $43 \%$ \\
\hline & No Experience & 89 & $45 \%$ \\
\hline
\end{tabular}

Table 2: Highest-ranked and lowest-ranked learners' beliefs

\begin{tabular}{|c|c|c|c|}
\hline Rank & Belief & $\begin{array}{c}\text { Agree/ } \\
\text { strongly agree }\end{array}$ & $\%$ \\
\hline 1 & $\begin{array}{l}\text { Learning vocabulary is an } \\
\text { important part of learning } \\
\text { English. }\end{array}$ & 194 & $98.5 \%$ \\
\hline 2 & $\begin{array}{l}\text { Learning the grammar is an } \\
\text { important part of learning } \\
\text { English. }\end{array}$ & 193 & $98 \%$ \\
\hline 3 & $\begin{array}{l}\text { In learning English, it is } \\
\text { important to practice a lot. }\end{array}$ & 192 & $97.5 \%$ \\
\hline 4 & $\begin{array}{l}\text { If I learn to speak English } \\
\text { very well, it will help me get } \\
\text { a good job. }\end{array}$ & 191 & $97 \%$ \\
\hline 5 & $\begin{array}{l}\text { If I get to speak English } \\
\text { very well, I will have many } \\
\text { opportunities to use it. }\end{array}$ & 187 & $95 \%$ \\
\hline 32 & $\begin{array}{l}\text { In learning English, it } \\
\text { is easier to speak than } \\
\text { understand what people say. }\end{array}$ & 36 & $18 \%$ \\
\hline 33 & $\begin{array}{c}\text { People who are good at } \\
\text { math and science are not } \\
\text { good at learning foreign } \\
\text { languages. }\end{array}$ & 25 & $13 \%$ \\
\hline 34 & $\begin{array}{l}\text { We should not say anything } \\
\text { in English until we can speak } \\
\text { it correctly. }\end{array}$ & 24 & $12 \%$ \\
\hline 35 & $\begin{array}{l}\text { English is structured in the } \\
\text { same way as Arabic. }\end{array}$ & 21 & $11 \%$ \\
\hline 36 & $\begin{array}{c}\text { English is a difficult language } \\
\text { to learn. }\end{array}$ & 20 & $10 \%$ \\
\hline
\end{tabular}

aptitude for learning a foreign language. This result concurs with the findings of Peacock (2001) who took this as an indication of lack of confidence on the part of the learners. The following table shows the results of the five top-ranked beliefs and the five bottomranked beliefs.

The second research question examines whether students' beliefs about English language learning change over their years of study in the English teacher training program. To answer this research question, participants' data were submitted to a one-way analysis of variance (ANOVA). Out of the 36 beliefs featured in the questionnaire, only six showed a significant change over the four-year duration of the program. There are significant differences in item 16 (I have a foreign language aptitude) $(F=3.533, p=.016)$, item 18 (In learning English, it is important to practice a lot) $(F=3.892, p=.01)$, item 19 (Learning vocabulary is an important part of learning English) ( $F=6.085, p$ $=.001$ ), item 21 (If you are allowed to make mistakes, in the beginning, it will be hard to get rid of them later on) $(F=2.085, p=.038)$, item 27 (Learning how to translate from Arabic is an important part of learning English $(F=4.517, p=.004)$, and item 35 (People who speak more than one language are intelligent) ( $F=$ 2.987, $p=.032$ ). Table 3 summarizes these findings.

To locate the source of differences among the four groups of students, a post-hoc Fisher test was performed. Multiple comparisons revealed the following differences for each of the 6 items: item 16 , freshmen vs. sophomores $(p=.045)$, freshmen vs. seniors $(p=.008)$, and juniors vs. seniors ( $p=$ $.013)$; item 18, freshmen vs. seniors ( $p=.007$ ) and sophomores vs. seniors ( $p=.005)$; item 19 , freshmen vs. juniors $(p=.03)$, freshmen vs. seniors $(p=.000)$, sophomores vs. juniors ( $p=.048$ ) and sophomores vs. seniors $(p=.001)$; item 21 , freshmen vs. seniors $(p=$ $.004)$; item 27 , sophomores vs. seniors ( $p=.013$ ), and juniors vs. seniors ( $p=.000)$; item 35 , freshmen vs. seniors $(p=.004)$.

Overall, the results show that 30 of the 36 beliefs did not undergo any significant changes during the length of study. This conclusion is in line with the findings of many researchers (see, e.g., Peacock, 2001; Powell, 1992; Tatto, 1998) who emphasized that learners' beliefs are deeply entrenched and tend to be very resistant to change. Where there are significant changes, the majority of cases show noticeable differences between students in the early stage of the program and students who are about to exit it. For example, the seniors group accords more importance to the role of aptitude than the freshmen group. In general, aptitude has increased between the first year and the final year of study, which, in a way, is an 
indication of the students' level of confidence in their ability to learn the foreign language. Surprisingly, the seniors group gives less importance to practicing the use of the language than both the freshmen and sophomore groups. Similarly, the two most senior groups seem to accord less significance to acquiring new vocabulary in learning a foreign language. The seniors' view on mistakes seems more logical than the other groups; they believe that making mistakes does not lead to the permanent fossilization of these mistakes. Moreover, the seniors group differs from the other groups in their perception of the role of translation in learning a new language. In addition, they, contrary to the findings of Horwitz (1985), give less importance to the role of intelligence in learning a foreign language than the other groups. Overall, the results for these six items, with the exception of item 16 , show that as students progress in the program they accord less importance to these five beliefs.

An interesting observation is that the students in all groups give high significance to the role of grammar in learning a language. As mentioned before, the role of grammar in learning a foreign language is ranked second among all beliefs. However, there is an overall decline by year given to this role. This decline is nonetheless not significant $(p=.108)$. The significance of grammar for students could be the result of training which emphasizes the role of grammar. In recent years, a preponderance of research on focus-onform instruction has resurrected the role of grammar as an essential component in building learners' competence in the foreign language (see, e.g., Ellis, 2001; Izumi, 2002; Leow, 2015; Long, 1991; Radwan, 2005). This resurgence in the role of grammar must have impacted teaching practices, thus positively influencing students' perception of its significance.

The third research question examines the impact of teaching experience on learners' beliefs. In this regard, it should be noted that as prospective teachers and as part of their program, the students are required to practice teaching English as a foreign language for a whole semester in government schools. For the purpose of this study, the students are divided into two groups: students with teaching experience and

Table 3: Variation in beliefs by students' year of study

\begin{tabular}{|l|c|c|c|c|c|c|}
\hline & Freshmen & Sophomores & Juniors & Seniors & & \\
\hline & \multicolumn{5}{|c|}{ Mean } \\
\hline Item 16 & 3.13 & 3.51 & 3.24 & 3.61 & 3.533 & .016 \\
\hline Item 18 & 4.75 & 4.74 & 4.52 & 4.39 & 3.892 & .01 \\
\hline Item 19 & 4.91 & 4.87 & 4.68 & 4.51 & 6.085 & .001 \\
\hline Item 21 & 3.53 & 3.15 & 3.04 & 2.71 & 2.085 & .038 \\
\hline Item 27 & 3.66 & 3.77 & 3.88 & 3.27 & 4.517 & .004 \\
\hline Item 35 & 4.19 & 3.9 & 3.89 & 3.57 & 2.987 & .032 \\
\hline
\end{tabular}

students with no teaching experience. A t-test was conducted on the students' data, and the results show a significant difference between experienced students and the other group with regard to four beliefs only: item 8 (it is good to speak English with good pronunciation) ( $\mathrm{t}=2.374, \mathrm{p}=.019)$; item 16 about aptitude $(\mathrm{t}=2.116, \mathrm{p}=.036)$; item 17 (Everyone can learn to speak English) ( $t=1.971, p=.05)$, and item 21 about mistakes $(t=2.702, p=.008)$. This shows that the students' teaching experience does not have a serious impact on their beliefs about language teaching and training, which again shows how stable and resistant to change these beliefs are. This finding is in line with the results obtained by Peacock (2001) who showed that students' experience shifted their beliefs about the significance of pronunciation in learning a foreign language, as they accorded it less importance than the other group. Additionally, the experienced students apparently have gained more confidence in their ability to acquire the language. However, it seems that their experience with students in government schools, who are generally weak in English, has led them to question the belief that 'everyone can learn to speak English.' In addition, their experience with students in public schools has impacted their views on errors, as they believe that mistakes do not preclude learning a foreign language. The fourth research question explores the relationship between beliefs and students' proficiency. Participants are divided into two groups: $\mathrm{B}$-and-above, and $\mathrm{C}$-andbelow, which is the less proficient group. A t-test was performed on the participants' data. The results reveal a significant difference between the proficient group and the less proficient group in only 3 items: item 6 (Females are better than males at learning English) ( $t$ $=2.193, p=.029$ ), item 16 about having aptitude ( $t=$ 2.033, $p=.043$ ), and item 32 (People who are good at math and science are not good at learning foreign languages) ( $t=2.761, p=.006)$, see Table 5 below. Interestingly, none of these items are part of Horwitz's core beliefs about language learning and teaching. The results show that the more proficient group agrees with item six more than the less proficient group. Considering that $85 \%$ of the population sample consists of female participants, this as a corollary is an expected result. Similarly, one would expect the

Table 4: Variation in beliefs by teaching experience

\begin{tabular}{|c|c|c|c|c|}
\hline & Experience & No Experience & & \\
\hline & \multicolumn{2}{|c|}{ Mean } & t-value & $\mathbf{P}$ \\
\hline Item 8 & 4.28 & 4.53 & 2.374 & .019 \\
\hline Item 16 & 3.51 & 3.26 & 2.116 & .036 \\
\hline Item 17 & 3.91 & 4.14 & 1.971 & .05 \\
\hline Item 21 & 2.79 & 3.26 & 2.702 & .008 \\
\hline
\end{tabular}


more proficient group to accord higher value for the aptitude in language learning, which is evident in the findings. In addition, both groups seem to reject the association between major and ability to learn a language, but the more proficient group rejects the statement significantly more than the other group. Overall, the results do not show a strong relationship between beliefs and proficiency. This result is similar to the findings of Tanka and Ellis (2003) who revealed that the relationship between beliefs and proficiency, as measured by TOEFL scores, was weak and nonsignificant.

While the above analysis shows that there is a relationship between certain beliefs and English proficiency, it does not specifically examine whether, if learners have a specific belief, their proficiency will be either lower or higher than those who do not hold the same belief. To run this type of analysis, data were recomputed and submitted to a chi-square analysis. Results show that participants who agree with the statement "I have a foreign language aptitude", are significantly more proficient than those who disagree with the belief $(X 2=6.073, p=.048)$. In addition, those who disagree with item 32 about math and science tend to be more proficient than those who agree with the statement. The results are shown in Table 6 below. To take the analysis to another level, this paper sought to find out which beliefs are predictive of success in learning a foreign language and gaining higher proficiency in English; the participants' data were submitted to multiple regression with all variables (gender, experience, year of study) controlled for and English proficiency as the grouping variable. Regression analysis shows significant differences between the two groups ( $R$ square $=.255, F=4.879, p=.000$ ), see Table 7 below. The results reveal that the items predictive of success in learning a foreign language are item 6 about gender differences $(t=2.439, p=$ $.016)$, item 10 about not saying anything before being able to speak it ( $t=2.500, p=.013$ ), item 16 about having aptitude for foreign languages, item 20 (I feel self-conscious when I speak in front of other people), and item 32 about math and science and language learning. According to these results, those who are likely to succeed in achieving higher proficiency levels in the target language are the ones who believe that females are better at learning languages than males

Table 5: Variation in beliefs by proficiency level

\begin{tabular}{|c|c|c|c|c|}
\hline & Proficient & Less Proficient & & \\
\hline & \multicolumn{2}{|r|}{ Mean } & $\mathrm{t}$-value & $P$ \\
\hline Item 6 & 3.07 & 2.77 & 2.193 & .029 \\
\hline Item 16 & 3.51 & 3.27 & 2.033 & .043 \\
\hline Item 32 & 2.20 & 2.58 & 2.761 & .006 \\
\hline
\end{tabular}

and those who accord less importance to the idea that students majoring in math and science are not good at languages. More importantly, the results show that students with high levels of confidence in their ability to learn a foreign language are likely to succeed in learning a foreign language. This finding concurs with a plethora of studies that confirm the strong role of aptitude in learning a language (see, e.g., Granena, 2016; Skehan, 2016). Successful learners also need to be less self-conscious when they use the language in front of others. This shows the importance of having high levels of confidence and high self-esteem in learning a foreign language. This finding is in line with research that emphasizes the significance of selfesteem and confidence in learning a foreign language (see, e.g., Dörnyei, 2005; Gardner \& Maclntyre, 1991; Roberts, 2002).

\section{Conclusion}

This study offers a wide array of interesting results. On the one hand, all students regardless of their year of study or proficiency level have strong beliefs about the role of grammar and vocabulary in learning a foreign language. These two traditional beliefs, which are associated, according to Peacock (2001) with low ESL proficiency, should be a cause of concern due to the fact that they imply less emphasis on the communicative nature of learning a foreign language. However, the fact that the students accord high levels of importance to practicing language, speaking and using other communicative activities, mitigates any negative and detrimental effects these beliefs might have. Considering that these students spent one whole year in an intensive English program prior to joining the English Department could explain why they give more significance to the role of practice and other communicative activities. This interest in practice and language use is also evident in their disagreement with the belief that says it is better to postpone speaking activities until after the student is sure that he could produce the language correctly. This position is further supported by their strong belief that speaking is easier than understanding, which gives students confidence in their ability to use

Table 6: Association between beliefs and EFL proficiency

\begin{tabular}{|c|c|c|c|c|c|}
\hline & Agree & Neither & Disagree & & \\
\hline & $\begin{array}{l}\text { Number/ } \\
\text { Percentage }\end{array}$ & $\begin{array}{l}\text { Number/ } \\
\text { Percentage }\end{array}$ & $\begin{array}{l}\text { Number/ } \\
\text { Percentage }\end{array}$ & Chi-square & $P$ \\
\hline \multirow{2}{*}{ Item 16} & 90 & 80 & 27 & 6.073 & .048 \\
\hline & $45.7 \%$ & $40.6 \%$ & $13.7 \%$ & & \\
\hline \multirow{2}{*}{ Item 32} & 25 & 61 & 111 & 8.234 & .016 \\
\hline & $12.7 \%$ & $31 \%$ & $56.3 \%$ & & \\
\hline
\end{tabular}


the new language in their communication.

Consistent with previous research findings (see, e.g., Horwitz, 1988; Peacock, 2001; Tatto, 1998), this study shows that students' beliefs are relatively stable, inflexible and resistant to change, changing only nominally over the duration of the four-year program. Of all beliefs about language learning and teaching, only six beliefs showed significant changes among students from different years of study. Most of the changes are mainly due to senior students having different perceptions of these beliefs than the freshmen group. As they progressed in the program, the senior students seemed to gain more confidence in their abilities to learn English, which is quite logical as extra years of rigorous training in all language components and skills will eventually add to their proficiency in the target language. Though the senior group continued to accord high status to the role of practice in learning a foreign language (mean $=4.39$ ), it is surprising that their mean is lower than the other groups. This could be attributed to the fact that in the final year of the program, the students spend most of their time in teacher training in public schools. Due to time constraints and prevailing methodologies used, students in these schools usually focus more on vocabulary and grammar. This, in turn, could have indirectly affected their views of the role of practice.

The senior students also showed a significant change in their beliefs about mistakes and the roles of translation and intelligence. These changes are very positive and can be beneficial to their students when they start their profession. Their views on the impact of errors is less rigid than the other groups. Errors are part of the learning process (Corder, 1981), and they can be indicative that the language learner is engaged in some type of hypothesis formation (Touchie, 1986). In addition, the training they received in the university has apparently changed their perception of the role of translation and intelligence. This is very significant as these students will join the teaching profession a few months after graduation. According a higher status to translation in language learning could be an indication of propensity towards the use of old methodologies which EFL research has long proved to be ineffective. Duff (1989) asserts that translation is not communicative in nature and has nothing to do with communicative language teaching. Similarly, Malmkjaer (2010) believes that translation provides students with false beliefs about one-to-one correspondence between two languages. Moreover, Carreres (2006) thinks that it can be a frustrating and demotivating practice in the classroom. As for intelligence, the decline in their views about the role of intelligence will help them work with all students and avoid excluding any group on the grounds that they do not possess the high levels of intelligence needed for language learning.

Experience in teaching does not seem to have a major impact on the students' beliefs. The views of students with teaching experience differed from those of the other group in only few beliefs. The experienced group seems to accord more importance to correct pronunciation, and they give less significance to the statement that 'everyone can learn to speak English.' These statements are, in a way, related. The students with teaching experience usually receive their training in public schools. Students in these schools generally demonstrate low levels of proficiency in language learning, and their English pronunciation is generally heavily accented due to the influence of their first language. This may frustrate these prospective teachers and lead them to conclude that not everyone can learn to speak a new language.

The study reveals a significant association between learners' level of confidence and success in learning a foreign language. This affective factor has been shown by many studies (see, e.g., Dörnyei, 2005; Gardner, Tremblay, \& Masgoret, 1997; Oxford, 1999) to play a positive role in helping learners acquire a new language. In addition, it is one of the beliefs that predict success in learning a new language. Moreover, the findings assert that controlling fear of making mistakes, which might hinder production, and overcoming feelings of self-consciousness are strong predictors of success in learning a language. This study, thus, shows that the beliefs about the role of cognitive and affective factors are critical for success in learning a new language.

In conclusion, the study shows that learners' beliefs about language learning manifest a degree of stability. This is why it is critical to work on shaping and amending students' beliefs early on in any teachers' training program. This requires a careful and, at the same time, prompt intervention in the early stages of students' professional training to "replace or otherwise modify the folk theories that already guide them" (Bruner 1996:46) and to equip them with theoretical and pedagogical beliefs necessary to affect their future students positively.

\section{References:}

Agathopoulou, E. (2010). EFL student teachers' beliefs and the effect of a second language acquisition course. In A. Psaltou-Joycey, \& Matthaioudakis, M. (Eds.), Advances in research on language acquisition and teaching (selected papers from the 14th international Conference of the Greek Applied Linguistics Society, Thessaloniki: Greek Applied Linguistics Association. 
Barcelos, A. (2003). Researching beliefs about SLA: A critical review. In P. Kalaja, \& A. Barcelos (Eds.), Beliefs about SLA (pp. 7-33). Dordrecht: Kluwer Academic Publishers.

Bartels, N. (2005). Researching applied linguistics in language teacher education. In N. Bartels (Ed.), Applied Linguistics and Language Teacher Education (pp. 1-26). New York: Springer.

Borg, S. (2006). Teacher cognition and language education. London, UK: Continuum.

Brown J., \& McGannon, J. (1998). What do I know about language learning? The story of the beginning teacher. Proceedings of the 1998 ALAA (Australian linguistics association of Australia) Congress.

Bruner, J. (1996). The Culture of Education. Harvard University Press. Cambridge, MA.

Carreres, A. (2006). Strange bedfellows: Translation and language teaching. The teaching of translation into L2 in modern languages degrees; uses and limitations. Sixth Symposium on Translation, Terminology and Interpretation in Cuba and Canada: December 2006. Canadian Translators, Terminologists and Interpreters Council.

Clark, C., \& Peterson, P. (1986). Teachers) thought processes. In Wiltrock, M. (Ed.), Handbook of Research on Teaching (pp. 255-296). New York: Macmillan.

Corder, S. Pit. (1981). Error Analysis and Interlanguage. Oxford: Oxford University Press.

Debreli, E. (2012). Change in beliefs of pre-service teachers about teaching and learning English as a foreign language throughout an undergraduate preservice teacher training program. Procedia - Social and Behavioral Sciences, 46, 367-373.

Dörnyei, Z. (2005). The psychology of the language learner: Individual differences in second language acquisition. London: Mahwah, New Jersey.

Duff, A. (1989). Translation. London: Oxford University Press.

Dweck, C. S. (2006). Mindset. New York: Ballantime.

Ellis, R. (2001). Introduction: Investigating formfocused instruction. Language Learning, 51(1), 1-46.

El-Okda. M. (2005). EFL student teachers' cognition about reading instruction. The Reading Matrix, 5(2),
43-60.

Erkmen, B. (2012). Ways to uncover teachers' beliefs. Procedia - Social and Behavioral Sciences, 7, 141- 46.

Fang, Z. (1996). A review of research on teacher beliefs and practices. Educational Research, 38(1), 47-65.

Feryok A. (2008). An Armenian English language teacher's practical theory of communicative language teaching. System, 36, 227-240.

Gardner, R., \& Macintyre, P. (1993). A student's contributions to second language learning. Part II: Affective variables. Language Teaching, 26, 1-11.

Gardner, R., Tremblay, P., \& Masgoret, A. (1997). Towards a full model of second language learning: An empirical investigation. The Modern Language Journal, 81, 344-362.

Graber, K. (1996). Influencing student beliefs: The design of a "high impact" teacher education program. Teaching and Teacher Education, 12, 451-466.

Granena, G. (2016). Explicit and implicit cognitive aptitudes and information-processing styles: An individual differences study. Applied Psycholinguistics, 37(3), 577-600.

Horwitz, E. (1985). Using students' beliefs about language learning and teaching in the foreign language methods course. Foreign Language Annals, 18, 333- 340.

Horwitz, E. (1987). Surveying student beliefs about language learning. In A. Wenden \& J. Rubin, (Eds.), Learner strategies in language learning (pp. 119-129). Englewood Cliffs, NJ: Prentice-Hall.

Horwitz, E. (1988). The beliefs about language learning of beginning university foreign language students. Modern Language Journal, 72(3), 283-294.

Izumi, S. (2002). Output, input enhancement, and the noticing hypothesis: An experimental study on ESL relativization. Studies in Second Language Acquisition 24, 541-577.

Joram, E., \& Gabriele, A. (1998). Preservice teachers' prior beliefs: Transforming obstacles into opportunities. Teaching and Teacher Education, 14, 175-191.

Kern, R. (1995). Students' and teachers' beliefs about language learning. Foreign Language Annals, 28, 71- 
91.

Koch, B. (1983). Presentation as proof: The language of Arabic rhetoric. Anthropological Linguistics, 25, 4760.

Leow, R. (2015). Explicit learning in the L2 classroom: A student-centered approach. New York, NY: Routledge.

Long, M., 1991. Focus on Form: A design feature in language teaching methodology. In: K. de Bot, R. Ginsberg, \& C., Kramsch, C. (Eds.), Foreign Language Research in Cross-cultural Perspective (pp. 39-52). John Benjamins, Amsterdam.

MacDonald M., Badger, R., \& White, G. (2001). Changing values: What use are theories of language learning and teaching? Teaching and Teacher Education, 17(8), 949-963.

Malmkjær, K. (2010). Language learning and translation. In Y. Gambier \& L. van Doorslaer (Eds.), Handbook of Translation Studies (pp. 185-190). Vol. 1. Amsterdam and Philadelphia: Benjam.

Mattheoudakis, M. (2007). Tracking changes in preservice EFL teacher beliefs in Greece: A longitudinal study. Teaching and Teacher Education, 23(8), 12721288.

Nettle, E. (1996). The development and use of scales for measuring student teachers) beliefs about teaching. (Unpublished doctoral thesis). The University of New South Wales, Sydney.

Nettle, E. (1998). Stability and change in the beliefs of student teachers during practice teaching. Teaching and Teacher Education, 14(2), 193-204.

Oxford, R. (1999). Anxiety and the Language Learner: New Insights. In J. Arnold (Ed.), Affect in Language Learning (pp. 58-67). Cambridge, UK: Cambridge University Press.

Pajares, M. (1992). Teachers' beliefs and educational research: Cleaning up a messy construct. Review of Educational Research, 62, 307-332.

Peacock, M. (2001). Pre-service ESL teachers' beliefs about second language learning: A longitudinal study. System, 29(2), 177-195.

Peacock, M. (1999). Beliefs about language learning and their relationship to proficiency. International Journal of Applied Linguistics, 9(2), 247-265.
Powell, R. (1992). The influence of prior experiences on pedagogical constructs of traditional and nontraditional preservice teachers. Teaching and Teacher Education, 8, 225-238.

Puchta, H. (1999). Beyond materials, techniques and linguistic analyses: The role of motivation, beliefs and identity. Plenary session at the LATEFL: 33rd International Annual Conference, Edinburgh, 64-72.

Radwan, A.A. (2005). The Effectiveness of Explicit Attention to Form in Language Learning. System, 33(1), 69-87.

Richards, J.C., \& Lockhart, C. (1996). Reflective teaching in second language classrooms. Cambridge, UK: Cambridge University Press.

Richardson, V. (2003). Preservice Teachers' Beliefs. In J. Raths, \& A. McAninch (Eds.), Teacher Beliefs and Classroom Performance: The Impact of Teacher Education (pp. 1-22). Greenwich, CT: Information Age Publishing.

Roberts, R. (2002). Self-esteem and early learning (2nd ed.). London: Paul Champman Publishing.

Samimy, K., \& Lee, Y. (1997). Beliefs about language learning: Perspectives of first-year Chinese learners and their instructors. Journal of the Chinese Language Teachers Association, 32, 40-60.

Sendan, F. (1995). Patterns of development in EFL student teachers' personal theories: A constructivist approach: Unpublished Doctoral Dissertation, University of Reading, UK.

Skehan, P. (2016). Foreign language aptitude, acquisitional sequences, and psycholinguistic processes. In G. Granena, D. Jackson \& Y. Yilmaz (Eds.), Cognitive individual differences in $L 2$ processing and acquisition. Amsterdam: John Benjamins

Tanaka, K., \& Ellis, R. (2003). Study-abroad, language proficiency, and learner beliefs about language learning. JALT Journal, 25(1), 63-85

Tatto, M. (1998). The influence of teacher education on teachers' beliefs about purposes of education, roles, and practices. Journal of Teacher Education, 49(1), 66-77.

Touchie, H. (1986). Second language learning errors their types, causes, and treatment. Proceedings of the JALT Journal, 8(1). 
Wenden, A. (1987). How to be a successful language learner: Insights and prescriptions from L2 learners. In A. Wenden \& J. Rubin (Eds.), Learner strategies in language learning (pp. 103-111). London, UK: Prentice-Hall. 